\title{
Dr. Richard C. Nelson: A Water Tower Remembrance
}

\author{
Robert Shapiro \\ University of Kentucky
}

\begin{abstract}
The author recalls his initial introduction to the field of biomechanics in the Penn State Biomechanics Laboratory, known as the Water Tower, and its positive and profound effect on his lifetime career. Under the directorship of Dr. Richard Nelson, Penn State's biomechanics program provided the author with a variety of both professional and personal learning opportunities. The author credits these experiences as having a direct relationship to his successful development as teacher, mentor, and researcher.
\end{abstract}

Keywords: baseball, International Society of Biomechanics, mentoring, graduate education

I graduated Brooklyn College in January 1972 with a degree in health and physical education. I expected to teach physical education and coach baseball. Unfortunately, no teaching jobs in physical education were open in New York City in the spring 1972.

Instead, I became the poster boy for teaching out of license, being hired to teach middle school mathematics on an emergency science license. I taught in a middle school located across the street from the Ebbets Field housing development. It was at best an eyeopening experience and at worst a very frustrating one. I did at least earn more money in 1 week than I had earned the previous several years working in summer camps, which would enable me to pursue graduate education to complete my teaching credentials.

I applied to a number of graduate programs around the country. While being admitted to all, none offered an assistantship. Upon the advice of one of my soccer coaches, I applied to Penn State and ultimately decided I would enroll there in the fall, whether or not I received financial support. At this time, I expected I would be taking courses related to teaching and would return to New York City after completing my master's degree. That summer I had a job in a camp in the Catskills, and from there, I moved to State College.

As an undergraduate student, I had several courses in calculus and physics before finally deciding on physical education as a major. I played on 2 varsity teams, baseball and soccer, and saw my future in teaching and coaching. Biomechanics research was not an area I had ever considered.

Fortunately for me, my math and science background caught the eye of Dr. Dewey Morehouse, director of the Sports Research Institute at Penn State. Evidently, the Sports Research Institute had an open research assistantship for fall 1972, and based upon my undergraduate coursework, he called while I was at camp and offered me the position. Needless to say, I accepted the offer. That is when my future changed direction unexpectedly and completely. My journey into biomechanics had begun.

Dr. Morehouse shared office space with Dr. Richard Nelson on the second floor of the Penn State Biomechanics Laboratory, better known as the Water Tower (Figure 1). My office was on the third floor, where I shared space with all the graduate students working in the biomechanics program. Unbeknownst to me, I was in the

Shapiro (23baseballny@gmail.com) is retired from the Department of Kinesiology and Health Promotion, University of Kentucky, Lexington, KY, USA. epicenter of biomechanics. Dick Nelson and Dewey Morehouse had created a sport biomechanics program at Penn State that was fast becoming one of the premier programs in the world. Soon after my arrival in State College, Dr. Peter Cavanagh arrived joining the faculty.

As Dr. Morehouse was on sabbatical my first semester, Dr. Nelson served as my advisor and provided my introduction to the field. Doing research was not on my radar when I left my undergraduate program. Suddenly, Dick Nelson was showing me how math and science could be applied to study sport. This was a perfect world.

The environment created by Dr. Nelson in the Biomechanics Laboratory, which happily included the Sports Research Institute, promoted collaboration and inclusivity. Everyone helped each other, worked hard and long without complaint. We played together as well, fielding a variety of intramural teams, drawing additional players from our colleagues in the exercise physiology program. Most notable among the teams was probably our softball team with Dick Nelson at third base and Dewey Morehouse at second base.

Social events were also held throughout the year with special ones held at Penn State's Stone Valley Recreation Center. I especially remember Dr. Nelson coming to a Halloween costume party, hosted by me and my wife in our apartment. Wearing a golf cap and his usual casual attire, he claimed his costume was that of a pro golfer.

What stands out in my memory was his ability to share in the experiences of his students as well as to mentor us. A key ingredient in Dick's leadership style was providing a family-like atmosphere within the work environment. Throughout my professional career, I tried very hard to emulate his example.

One of the most exciting times for the lab at Penn State was in 1973 hosting the Fourth International Seminar of Biomechanics organizational meeting at which the International Society of Biomechanics was formed. We met biomechanists from all over the world, forming friendships and collaborations that would last a lifetime. Drs. Nelson and Morehouse were instrumental in the formation of the society and helped lead it for many years.

It was at this meeting that I met Chuck Dillman, an early graduate of the Penn State biomechanics program under Dr. Nelson. After obtaining my master's at Penn State, Chuck became my $\mathrm{PhD}$ supervisor at the University of Illinois. I am always amazed at meetings when people are asked to stand if they are 


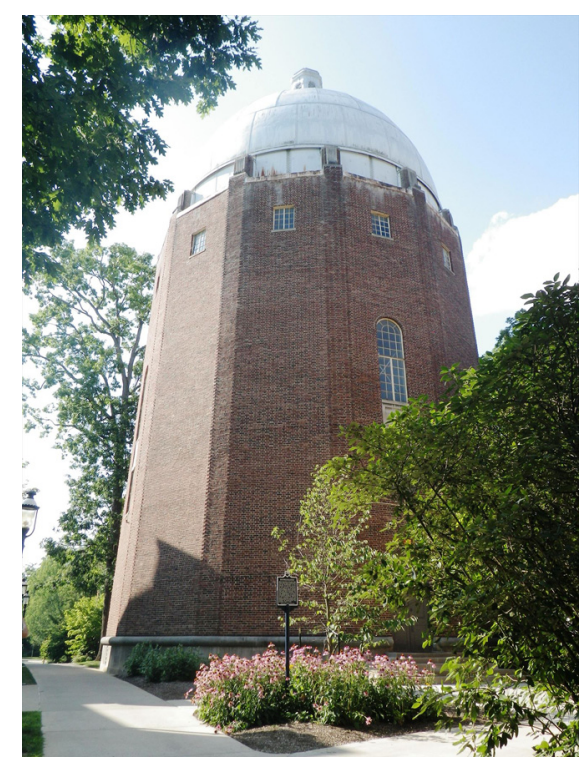

Figure 1 - The Water Tower, which was the longtime home of the Penn State Biomechanics Laboratory. somehow professionally related to Dick Nelson. I can proudly say he is my professional grandfather, being Chuck's advisor, as well as my uncle, for serving on my master's committee.

When it came time to choose a master's thesis topic, I was given the freedom to choose one of particular interest to me, the mechanics of baseball batting. Lab support for the project was amazing, including securing a pitching machine from the Pittsburgh Pirates and a "cherry picker" from the maintenance crew at Penn State used to obtain an overhead view. I could not have imagined at the time that my subsequent research on baseball biomechanics during my academic career would result in a collection of this work being housed at the Baseball Hall of Fame in Cooperstown.

In my retirement, now looking back upon my Penn State era from the fall 1972 through summer 1974, it was the "best of times" for me. The experience formed the foundation of my career in biomechanics. Even more, I appreciate the friendships and working relationships with Bob Gregor, Jim Walton, Dave Dainty, Terry Ward, Dan Daly, Arnie Goldfuss, Brian Bergemann, Gavin Reid, Bill Morrison, Chris Baster-Brooks, Peter Cavanagh, Ken Petak, John Palmgren, and all the biomechanists who were drawn to the Water Tower, thanks to Dick Nelson. 